NASZA DERMATOLOGIA Onlin OUR DERMATOLOGY Online

Source of Support: Nil

Competing Interests: None

\section{HERPES ZOSTER ON SEGMENTAL VITILIGO: ISOTOPIC} RESPONSE?

\author{
Mankesh Lal Gambhir, Kritika Pandey, Tejinder Kaur
}

Department of Dermatology, Venereology \& Leprosy, Government Medical College, Amritsar, Punjab, India

Corresponding author: Ass. Prof. Mankesh Lal Gambhir

\begin{abstract}
"Wolf's isotopic response" describes the occurrence of a new skin disorder at the site of another, unrelated and already healed skin disease. In most cases of isotopic response, the initial dermatosis is herpes zoster, herpes simplex, varicella, thrombophlebitis, scrofuloderma and striae distense. The most frequent second dermatoses are granulomatous reactions, particularly granuloma annulare, and lichenoid diseases. Various etiological reasons including viral, immunologic, neural and vascular have been put forth. We report here a case in which the second disease was herpes zoster that appeared over the same dermatomes of pre-existing segmental vitiligo. The occurrence of vitiligo as first and herpes zoster as second disease in the "Wolf's isotopic response" has not, to the best of our knowledge, been reported previously.
\end{abstract}

Key words: vitiligo; herpes zoster; isotopic response

Cite this article:

Gambhir ML, Pandey K, Kaur T. Herpes zoster on segmental vitiligo: Wolf's isotopic response? Our Dermatol Online. 2014; 5(2): 155-156.

\section{Introduction}

"Wolf's isotopic response" describes the occurrence of a new skin disorder at the site of another, unrelated and already healed skin disease. In most cases of isotopic response, the initial dermatosis is herpes zoster, herpes simplex, varicella, thrombophlebitis, scrofuloderma and striae distense. The most frequent second dermatoses are granulomatous reactions, particularly granuloma annulare, and lichenoid diseases. Various etiological reasons including viral, immunologic, neural and vascular have been put forth.

We report here a case in which the second disease was herpes zoster that appeared over the same dermatomes of pre-existing segmental vitiligo. The occurrence of vitiligo as first and herpes zoster as second disease in the "wolf's isotopic response" has not, to the best of our knowledge, been reported previously.

\section{Case Report}

A 56 year old female presented with a two day history of multiple vesicular lesions with burning pain at the site of depigmented patches of vitiligo of 8 years duration of the same region. On examination there were grouped vesicles distributed in a dermatomal fashion over the right mid thoracic region (T5-T6). On the background were the depigmented patches of segmental vitiligo involving T2-T6 thoracic dermatome (Fig 1). A clinical diagnosis of herpes zoster with segmental vitiligo of the same dermatome was made. Tzanck smear showed multinucleated giant cells. Routine investigations were normal. Oral acyclovir tablets $800 \mathrm{mg}$ five times daily were given for 7 days. The lesions healed completely within two weeks, with minimal scarring.

\section{Discussion}

The term, "Wolf's isotopic response", describes the occurrence of a new skin disorder at the site of another, unrelated and already healed skin disease [1]. It is important that the primary disease should have healed before the onset of the subsequent disease for it to be labeled as an isotopic response, to avoid mistaking it for reactivation of the primary disease, especially if the subsequent disease arise immediately [2]. In most cases of isotopic response, the initial dermatosis is herpes zoster [1], herpes simplex [3], varicella [3], thrombophlebitis [3], scrofuloderma [4] and striae distense [5].

The most frequent second dermatoses are granulomatous reactions, particularly granuloma annulare, and lichenoid diseases. Others are comedones and acneiform eruptions, tinea, furunculosis, contact dermatitis, nodular solar degeneration, morphea, graft-versus-host disease, eosinophilic dermatosis, reactive perforating collagenosis, lymphomas and leukemias, Kaposi sarcoma, angiosarcoma, vitiligo, basal cell carcinomas, squamous cell carcinomas and viral infections such as molluscum contagiosum or common warts. 


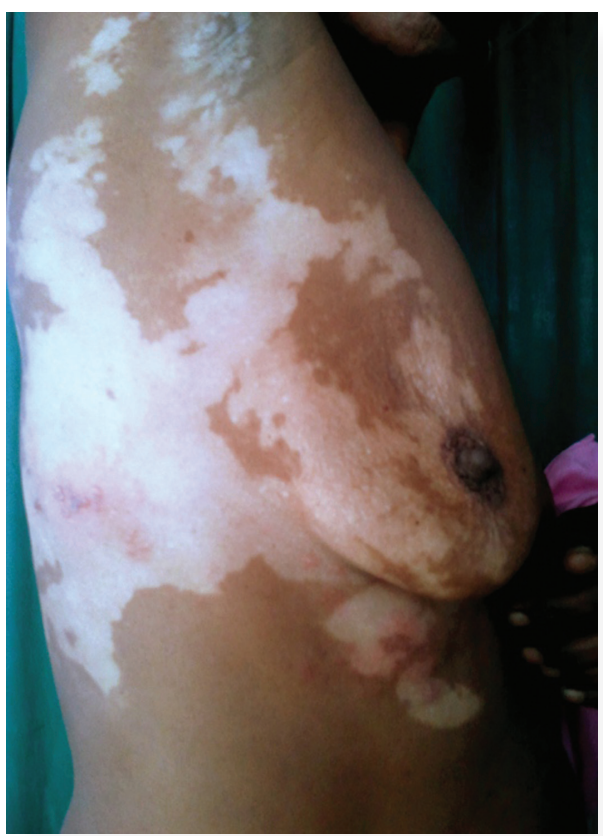

Figure 1. Herpes Zoster over segmental vitiligo: isotopic phenomenon.

A case of herpes simplex on scrofuloderma has been described $[4,6]$.

Viral, immunologic, neural and vascular etiologic reasons have been put forth. Immunologic changes like an increased sensitivity to tissue antigens in the primary viral infection, scarring, altered microcirculation, collagen rearrangement, and an imperfect skin barrier have been described. The main possibilities were that: the first disease causes skin changes that lead to the occurrence of a second disease at the same site; each event is being caused by a different stimulus; a coincidence factor; and a "locus minoris resistentiae" which means "an area, site, structure or organ of lessened resistance, genetically inherited or acquired, offering little resistance to invasion by micro-organisms and/or their toxins" [2-4,7,8].

Alternatively, some authors proposed that altered tissue antigens might be playing a role in the pathomechanism of this phenomenon. The skin's memory may last a lifetime and this is particularly true concerning the immunologic memory [4]. Researchers have recently proposed the role of tumor necrosis factor $(\mathrm{TNF} \alpha)$ in the immune response to herpes zoster and in a wide variety of inflammatory skin diseases, which may explain the occurrence of different diseases at same site [6].

Another interesting postulation puts forth is of bi-directional neuroimmunologic interaction. The secretion of neuropeptides from sensory nerve fibers in the skin has a variety of effects on mast cells, T-lymphocytes, monocytes and endothelial cells [4]. In many of the already reported cases a viral disease (herpes zoster or herpes simplex) was the first disease. It was assumed that the viral particles remaining in the tissue were responsible for the occurrence of a second disease $[2,3,7,9,10]$.

We report here a case of "Wolf's isotopic phenomenon" in which the second disease was herpes zoster that appeared over the same dermatomes of pre-existing segmental vitiligo. The occurrence of vitiligo as first and herpes zoster as second disease in the "wolf's isotopic response" has not, to the best of our knowledge, been reported previously.

\section{REFERENCES}

1. Wolf R, Brenner S, Ruocco V, Filioli FG. Isotopic response. Int J Dermatol. 1995;34:341-8.

2. Huang CW, Tu ME, Wu YH, Lin YC. Isotopic response of fungal granuloma following facial herpes zoster infections - report of three cases. Int J Dermatol. 2007;46:1141-5.

3. Requena L, Kutzner H, Escalonilla P, Ortiz S, Schaller JS, Rohwedders A. Cutaneous reactions at sites of herpes zoster scars: an expanded spectrum. Br J Dermatol. 1998;138:161-8.

4. Sharma RC, Sharma NL, Mahajan V, Sharma AK. Wolf's isotopic response: Herpes simplex appearing on scrofuloderma scar. Int $\mathrm{J}$ Dermatol. 2003;42:664-6.

5. Thappa D. Isotopic response versus isomorphic response. Indian J Dermatol Venereol Leprol. 2004;70:36.

6. Jaka-Moreno A, López-Pestaña A, López-Núñez M, OrmaecheaPérez N, Vildosola-Esturoa S, Tuneu-Valls A, et al. Wolf's Isotopic Response: A Series of 9 Cases. Actas Dermosifiliogr. 2012;103:798805 .

7. Tuzun Y, Iscimen A, Goksugur N. Wolf's isotopic response: Trichophyton rubrum folliculitis appearing on a herpes zoster scar. Int J Dermatol. 2000;39:766-8.

8. Sharma RC, Sharma NL, Mahajan V, Sharma AK. Wolf's isotopic response - lichen planus at the site of healed herpes zoster in an Indian woman. Int J Dermatol. 2003;42:664-6.

9. Gibney MD, Nahass GT, Leonardi CL. Cutaneous reactions following herpes zoster infection: report of three cases and a review of literature. Br J Dermatol. 1966;134:504-9.

10. Shemer A, Weiss G, Trau H. Wolf's isotopic response: a case of zosteriform lichen planus on the site of healed herpes zoster. J Eur Acad Dermatol Venereol. 2001;15:445-7.

Copyright by Mankesh Lal Gambhir, et al. This is an open access article distributed under the terms of the Creative Commons Attribution License, which permits unrestricted use, distribution, and reproduction in any medium, provided the original author and source are credited. 